\title{
Effects of Light Condition on Growth and Physiological Characteristics of the Endangered Species Sedirea japonica under RCP 6.0 Climate Change Scenarios
}

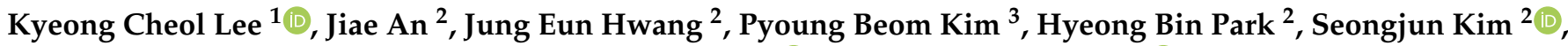 \\ Hwan Joon Park ${ }^{2}$, Chang Woo Lee ${ }^{2}$, Byoung-Doo Lee ${ }^{2}$ (D) and Nam Young Kim ${ }^{2, *}$ (i) \\ 1 Department of Forestry, Korea National College of Agriculture and Fisheries, Jeonju 54874, Korea; \\ dlrud112@korea.kr \\ 2 Research Center for Endangered Species, National Institute of Ecology, Yeongyang 36531, Korea; \\ jiae_an@nie.re.kr (J.A.); hwangje@nie.re.kr (J.E.H.); phb1274@nie.re.kr (H.B.P.); dao1229@nie.re.kr (S.K.); \\ rhg9281@nie.re.kr (H.J.P.); jacky903@nie.re.kr (C.W.L.); bdlee@nie.re.kr (B.-D.L.) \\ 3 Wetland Center, National Institute of Ecology, Changnyeong 50303, Korea; normal@nie.re.kr \\ * Correspondence: skadud2@nie.re.kr; Tel.: +82-054-680-7280
}

Citation: Lee, K.C.; An, J.; Hwang, J.E.; Kim, P.B.; Park, H.B.; Kim, S.; Park, H.J.; Lee, C.W.; Lee, B.-D.; Kim, N.Y. Effects of Light Condition on Growth and

Physiological Characteristics of the Endangered Species Sedirea japonica under RCP 6.0 Climate Change Scenarios. Plants 2021, 10, 1891. https://doi.org/10.3390/ plants10091891

Academic Editor: Fermin Morales

Received: 9 August 2021

Accepted: 7 September 2021

Published: 13 September 2021

Publisher's Note: MDPI stays neutral with regard to jurisdictional claims in published maps and institutional affiliations.

Copyright: (c) 2021 by the authors. Licensee MDPI, Basel, Switzerland This article is an open access article distributed under the terms and conditions of the Creative Commons Attribution (CC BY) license (https:// creativecommons.org/licenses/by/ $4.0 /)$.

\begin{abstract}
This study was conducted to evaluate the physiological and growth responses of Sedirea japonica cultured in chambers under RCP 6.0 and different light conditions. S. japonica was grown in a soil-plant daylight system chamber under two treatments, a control $\left(\mathrm{CO}_{2}=400 \mathrm{ppm}\right)$ and a climate change treatment $(\mathrm{CCT})\left(\mathrm{CO}_{2}=650 \mathrm{ppm}\right.$, temperature $=$ control $\left.+3{ }^{\circ} \mathrm{C}\right)$, and three different shading treatments $(60 \%, 90 \%$, and no-shading). S. japonica showed the characteristics of typical Crassulacean acid metabolism (CAM) plants. As the shading rate increased, it increased chlorophyll content, leaf area, and leaf dry weight to efficiently absorb and use light. The CCT had a lower $\mathrm{CO}_{2}$ absorption rate, stomatal conductance, and growth rate and slightly higher water utilization efficiency than the control. This was because stomatal closure occurred in the CCT to reduce water loss due to a relatively higher temperature. As $\mathrm{CO}_{2}$ fixation decreased and consumption increased due to respiration, the overall growth was inhibited. The CCT without shading revealed a dynamic photoinhibition phenomenon showing a significant increase in ABS/RC, TRo/RC, ETo/RC, and DIo/RC and a decrease in PI $\mathrm{ABS}$ and DF ABS. In this group, leaf, root, and total dry weight, chlorophyll content, and carotenoid content were the worst growth indices.
\end{abstract}

Keywords: climate change; photoinhibition; chlorophyll florescence; $\mathrm{CAM}$ plant; $\mathrm{CO}_{2}$ exchange rate; SPDS chambers

\section{Introduction}

Sedirea japonica is a small epiphytic orchid that grows on a rock or tree and is characterized by $4-10$ light greenish-white flowers in a racemose inflorescence between June and August [1]. S. japonica is found in Korea, China, Japan, and Taiwan, however, it has almost disappeared in the wild due to indiscriminate harvesting [2,3]. It is registered as an endangered species in Japan and designated as a level 1 endangered species by the Ministry of Environment in South Korea [2,3]. In particular, it is considered to be extinct in the natural condition because no indigenous plant has been reported in the last 20 years, except for the cultivated plants transplanted into nature [3]. The Ministry of Environment has designated it as a priority restoration target species and has initiated a restoration project [3].

Climate change, which is accelerating due to anthropogenic activities, is a major impediment to biodiversity, and it threats the survival of endangered species with high ecological vulnerabilities, such as S. japonica $[4,5]$. The 5th Assessment Report presented by the Intergovernmental Panel on Climate Change (IPCC) indicated that when the global mean temperature increases by $1.5-2.5^{\circ} \mathrm{C}$ or more, it will have a negative and irreversible 
effect on biodiversity and ecosystems, e.g., approximately $20-30 \%$ of the animal and plant species included in the assessment would become extinct and their geographical distribution range would be greatly altered [4].

The representative concentration pathways (RCP) scenario, showing a broad range of future climate changes, refers to the degree of influence that changes the energy balance due to radiative forcing, e.g., greenhouse gases [4]. Four RCP scenarios (2.6, 4.5, 6.0, and 8.5) are the most widely used [4]. Among these, RCP 6.0 is a representative intermediate scenario, indicating a condition wherein the greenhouse gas reduction policy has been achieved to some extent. Based on the temperatures recorded between 1986 and 2005, the mean surface temperature of Earth is predicted to increase by $1.4-3.1^{\circ} \mathrm{C}$ in 2081 to 2100 [6]. The climate change forecast data based on the Korean Peninsula predicts that carbon dioxide $\left(\mathrm{CO}_{2}\right)$ concentration will increase by $670 \mathrm{ppm}$ and the temperature will increase by $2.7^{\circ} \mathrm{C}$ in the RCP 6.0 scenario [7]. For investigations on the effects of climate change conditions on the growth of endangered species, it is necessary to conduct an overall assessment of the vulnerable species so as to preserve them as well as to determine the relationship between physiological characteristics of each species and environmental factors.

An increase in atmospheric $\mathrm{CO}_{2}$ concentration is expected to increase the photosynthetic rate and growth due to the $\mathrm{CO}_{2}$ fertilization effect $[8,9]$. Furthermore, the growth of Crassulacean acid metabolism (CAM) plants are also reported to increase [10]. However, the $\mathrm{CO}_{2}$ fertilization effect cannot exclude other environmental factors [11], and further investigations on complex environmental changes, including light conditions, need to be conducted.

Until recently, studies on S. japonica have conducted lineage and species identification using nucleotide sequences [1], pollination [2], and habitat suitability assessments [3]. However, there are few studies on their physiological and ecological characteristics and the effect of climate change. Therefore, this study aimed to provide the baseline data for establishing conservation strategies for $S$. japonica, an endangered species, by evaluating the effects of climate change (RCP 6.0) and different light conditions on its growth and physiological characteristics.

\section{Results and Discussion}

\subsection{Comparison of Environmental Conditions}

The mean daily temperature of the control samples decreased from $25.3^{\circ} \mathrm{C}$ in August to $18{ }^{\circ} \mathrm{C}$ in November and that of the CCT samples was $2.9^{\circ} \mathrm{C}$ higher than that of the control samples on average. Moreover, $60 \%$ and $90 \%$ shading decreased the room temperature by approximately $1.8^{\circ} \mathrm{C}$ and $3.3^{\circ} \mathrm{C}$, respectively, compared to no shading. Although the relative humidity was initially set at $70 \%$, it was not kept constant. During the experiment, the daily mean relative humidity was $58.3 \%$ and $49.1 \%$ for the control and CCT samples, respectively, showing a 9\% difference. In particular, the difference in daily mean relative humidity between the control and CCT samples was not large from August to mid-September; however, it became larger after mid-September (Figure 1).

\subsection{Daily Change in $\mathrm{CO}_{2}$ Absorption Rate and Stomatal Response}

S. japonica exhibited the characteristics of a typical CAM plant that absorbs $\mathrm{CO}_{2}$ mainly at night (Figure 2). $\mathrm{CO}_{2}$ emission and absorption are switched right before sunset (Phase IV). It absorbed a relatively high level of $\mathrm{CO}_{2}$ steadily from 7 p.m. (Phase I), and the absorption rate started to rapidly decrease after 5 a.m. (Phase II). It closes the stomata and stops $\mathrm{CO}_{2}$ absorption at sunrise (around 6-7 a.m.) and fixes $\mathrm{CO}_{2}$ again via the Calvin cycle during the daytime (Phase III) [12] $\mathrm{CO}_{2}$ is fixed mainly from night to before sunrise by phosphoenolpyruvate carboxylase. It is temporarily stored in the vacuoles in the form of malic acid (C4) through oxaloacetic acid, and then it is again fixed to ribulose 1,5-bisphosphate by ribulose-1,5-bisphosphatecarboxylase/oxygenase (RuBisCo) during the daytime [13]. 


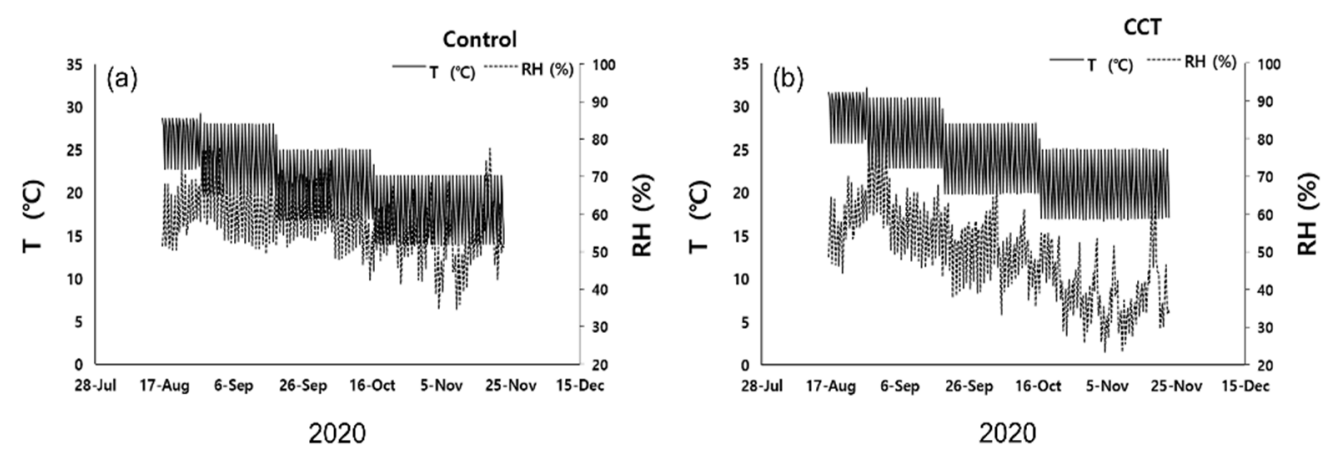

Figure 1. Changes of temperature (T) and relative humidity (RH) of Sedirea japonica under control $\left(\mathrm{CO}_{2}=400 \mathrm{ppm}\right)$ (a) and $\mathrm{CCT}$ (climate change treatment, $\mathrm{CO}_{2}=650 \mathrm{ppm}$, temperature $=$ control $\left.+3{ }^{\circ} \mathrm{C}\right)(\mathbf{b})$ during the experimental period.
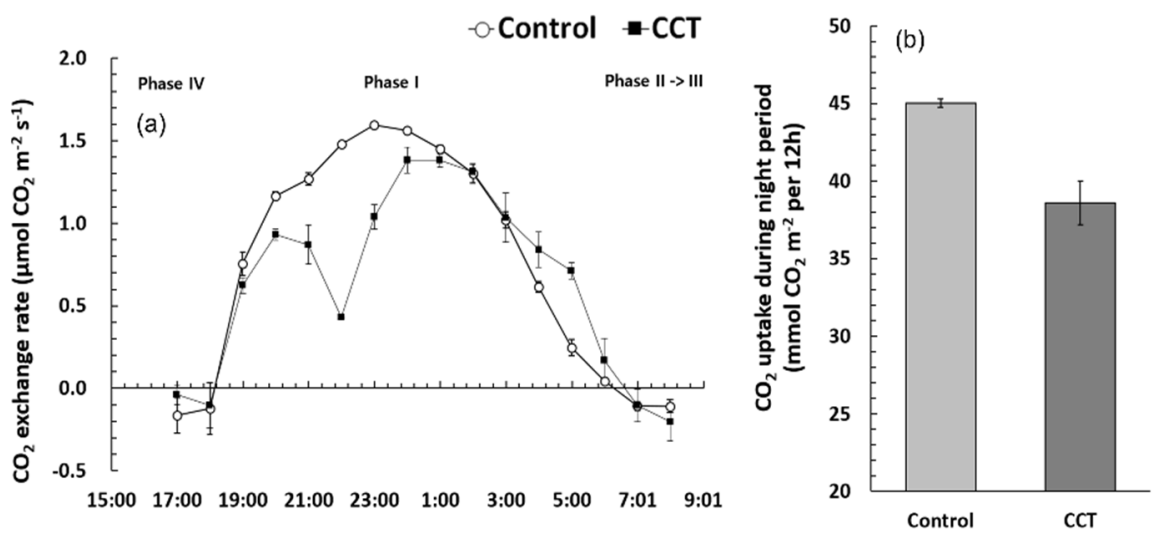

Figure 2. Changes of $\mathrm{CO}_{2}$ exchange rate (a) and $\mathrm{CO}_{2}$ uptake during night period (b) of Sedirea japonica under control $\left(\mathrm{CO}_{2}=400 \mathrm{ppm}\right.$ ) and CCT (climate change treatment, $\mathrm{CO}_{2}=650 \mathrm{ppm}$, temperature $=$ control $\left.+3{ }^{\circ} \mathrm{C}\right)$ conditions. Each value is expressed as the mean $\pm \operatorname{SD}(n=3)$.

The control samples clearly showed changes in the $\mathrm{CO}_{2}$ exchange rate, whereas the CCT samples showed a slightly decreasing absorption rate from 10 to 11 p.m. and then a recovering trend (Figure 2a). In general, the daily carbon assimilation rate of CAM plants is low; approximately $1 / 2$ of that of C3 plants and $1 / 3$ of that of C4 plants [13]; for S. japonica, it was up to $1.6 \mu \mathrm{mol} \mathrm{CO} \mathrm{Cm}^{-2} \mathrm{~s}^{-1}$ (Figure 2).

Various types of CAM plants tend to absorb more $\mathrm{CO}_{2}$ as the atmospheric $\mathrm{CO}_{2}$ concentration increases [10]. When the atmospheric $\mathrm{CO}_{2}$ concentration is doubled, the daily $\mathrm{CO}_{2}$ uptake of Ananas comosus increased by approximately $15 \%$ [14], that of Agave salmiana increased by approximately $59 \%$ [15], and that of Phalaenopsis increased by approximately 25 to $31 \%$ [16]. This reaction is highly related to the activity of RuBisCo in Phases II and $\mathrm{IV}$, where the stomata open and close. High atmospheric $\mathrm{CO}_{2}$ concentration increases the activity of RuBisCo, thus increasing the amount of $\mathrm{CO}_{2}$ fixation $[10,17]$.

Upon comparing the $\mathrm{CO}_{2}$ uptake by $S$. japonica during the night (Figure 2b), it was found that the control samples fixed $45.0 \mathrm{mmol} \mathrm{CO} \cdot \mathrm{m}^{-2}$ and the CCT samples fixed $38.6 \mathrm{mmol} \mathrm{CO} 2 \cdot \mathrm{m}^{-2}$, indicating that the control samples absorbed $17 \%$ more $\mathrm{CO}_{2}$. Previous studies on the response of CAM plants to the increase in atmospheric $\mathrm{CO}_{2}$ concentration were conducted under the same temperature conditions, however, the CCT showed increases in temperature of $\geq 3{ }^{\circ} \mathrm{C}$ compared to the control and increased atmospheric $\mathrm{CO}_{2}$ concentration in the chamber. In other words, it can be considered that, when S. japonica samples were grown under a relatively high temperature for a long time, the net daily $\mathrm{CO}_{2}$ uptake decreased because more stomata closed to prevent loss of moisture. In some CAM plants, such as Clusia uvitana and Portulacaria afra, it has been reported that $\mathrm{CO}_{2}$ uptake at night becomes stagnant or decreases under a moisture stress condition, even if 
the atmospheric $\mathrm{CO}_{2}$ concentration increases $[18,19]$. These results also imply that $\mathrm{CO}_{2}$ uptake is closely related to stomatal opening and closing.

In the control samples, $\mathrm{g}_{\mathrm{s}}$ and E rapidly increased after 6 p.m., maintained a high value, and then considerably decreased after 3 a.m. In contrast, in the CCT samples, the increase was relatively small, and the values were generally lower than those of the control samples until 3 a.m. (Figure $3 a, b)$. This trend showed that the CCT samples could not absorb $\mathrm{CO}_{2}$ in the atmosphere smoothly because they were not able to quickly switch from closed stomata during the daytime to opened stomata during the night compared to the controls. This is believed to be the result of adaptation to stomatal opening and closing to prevent loss of moisture while growing for a long time under higher mean temperature conditions (higher than at least $3{ }^{\circ} \mathrm{C}$ ) than the control. The WUEi and ITE of the CCT samples were higher than those of the control, supporting this result (Figure 3c,d). A similar trend was also observed for other CAM species such as Agave deserti [20], Opuntia ficus-indica [21], and Phalaenopsis spp. [22].
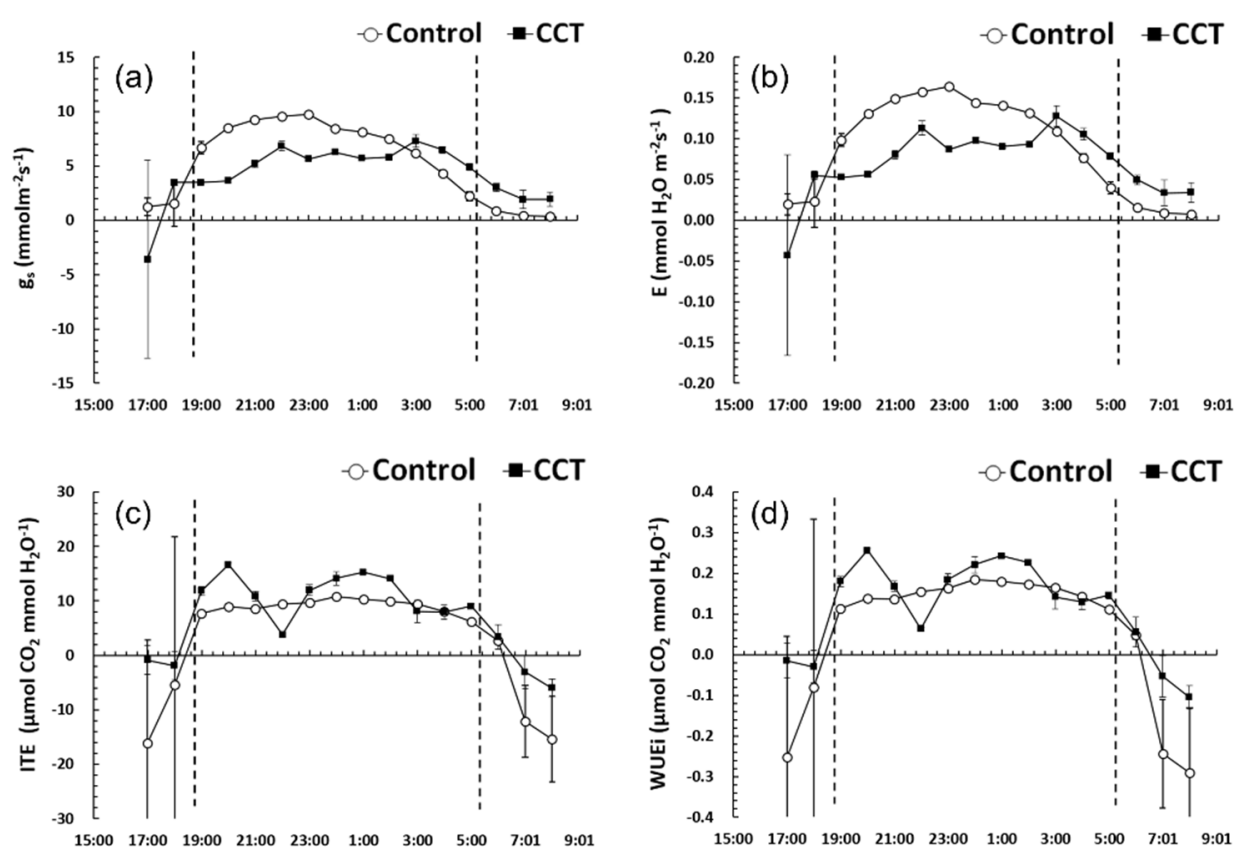

Figure 3. Changes of stomatal conductance $\left(\mathrm{g}_{\mathrm{s}}\right)(\mathbf{a})$, stomatal transpiration rate (E) (b), instantaneous transpiration efficiency (ITE) (c), and intrinsic water use efficiency (WUEi) (d) of Sedirea japonica under control $\left(\mathrm{CO}_{2}=400 \mathrm{ppm}\right.$ ) and $\mathrm{CCT}$ (climate change treatment, $\mathrm{CO}_{2}=650 \mathrm{ppm}$, temperature $=$ control $\left.+3^{\circ} \mathrm{C}\right)$ conditions. Each value is expressed as the mean $\pm \operatorname{SD}(n=3)$.

\subsection{Chlorophyll Fluorescence Response}

The chlorophyll fluorescence analysis determined the imbalance between the light energy absorbed by photochemical reactions and the energy used in electron transfer reactions. In particular, the OKJIP curve shows physiological responses to various environmental stresses quantitatively through changes in energy flow in photosystem II [13,23].

When monitoring the chlorophyll fluorescence response according to the climate change conditions and shading rate, $\mathrm{ABS} / \mathrm{RC}, \mathrm{TRo} / \mathrm{RC}, \mathrm{ETo} / \mathrm{RC}$, and DIo/RC, which indicate the change in energy flow per reaction center, were the lowest in the $90 \%$ shading control samples (control 90\%). In contrast, the ABS/RC and DIo/RC of the CCT samples without shading (CCT $0 \%)$ were significantly $(p<0.05)$ higher than other treatments from day 42 , and ETo/RC and TRo/RC were also the highest around day 55 after treatment (Figure $4 \mathrm{a}-\mathrm{d}$ ). 

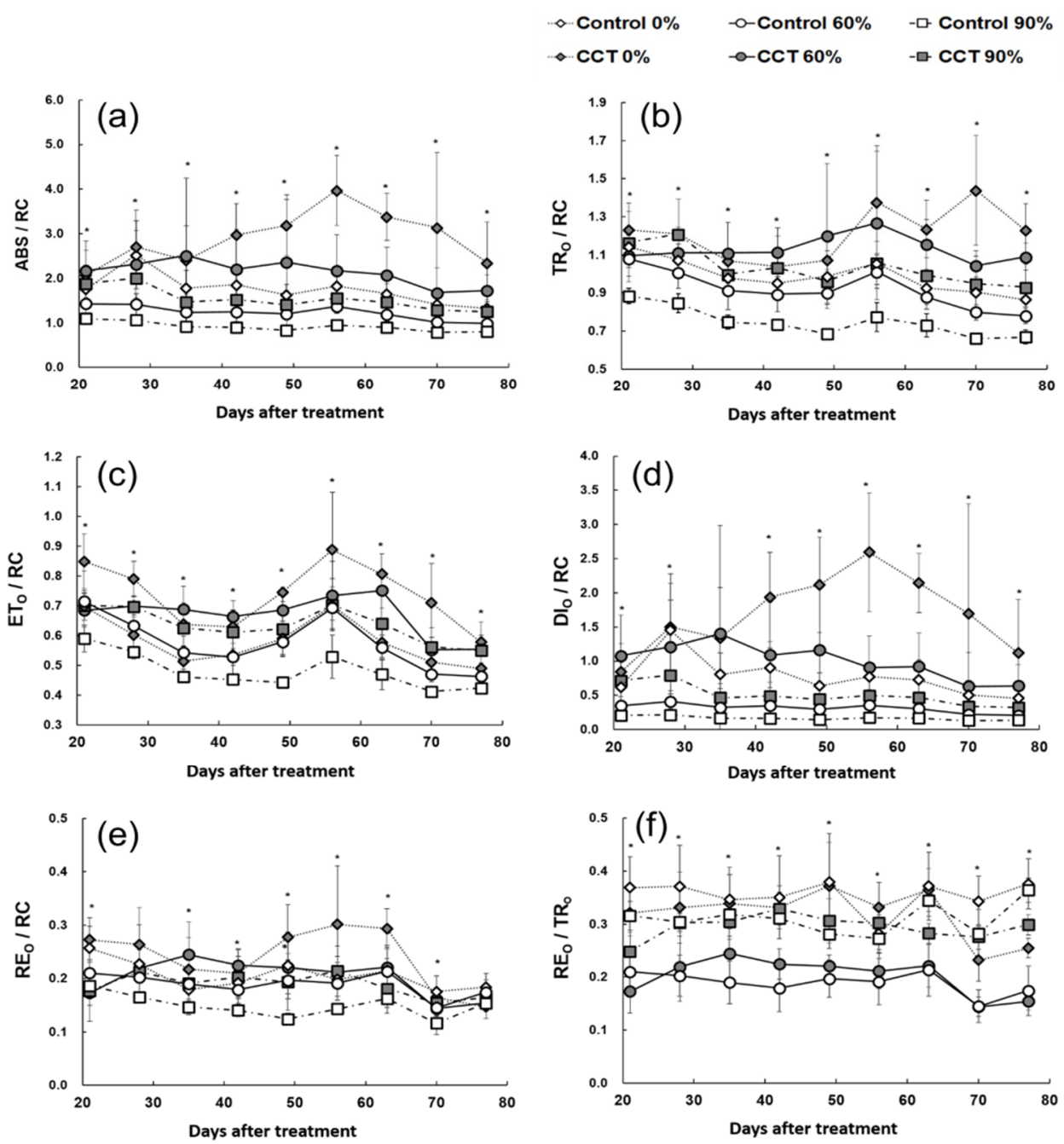

Figure 4. Effects of shading level on several chlorophyll fluorescence parameters (ABS/RC (a), $\mathrm{TR}_{0} / \mathrm{RC}(\mathbf{b}), \mathrm{ET}_{0} / \mathrm{RC}(\mathbf{c}), \mathrm{DI}_{0} / \mathrm{RC}(\mathbf{d}), \mathrm{RE}_{0} / \mathrm{RC}(\mathbf{e})$, and $\left.\mathrm{RE}_{0} / \mathrm{TR}_{0}(\mathbf{f})\right)$ of Sedirea japonica under control $\left(\mathrm{CO}_{2}=400 \mathrm{ppm}\right)$ and $\mathrm{CCT}$ (climate change treatment, $\mathrm{CO}_{2}=650 \mathrm{ppm}$, temperature $=$ control $+3{ }^{\circ} \mathrm{C}$ ) conditions. Each value is expressed as the mean $\pm \operatorname{SD}(n=5)$. The asterisk indicates significance at $p<0.05$.

$\mathrm{ABS} / \mathrm{RC}$ indicates light energy absorbed per reaction center, and DIo/RC refers to the light energy dissipated as heat [23]. The increase in ABS/RC and DIo/RC in the CCT 0\% treatment samples can be understood as a mechanism to prevent damage to the photosynthetic apparatus under strong light and relatively high temperature conditions $[24,25]$. It can be seen that it deactivates the reaction center and dissipates the excitation energy as heat $[24,25]$.

Moreover, TRo/RC and ETo/RC refer to changes in light energy captured in photosystem II per reaction center and changes in energy transferred to the electron transport system afterward [23]. It was found that although S. japonica has a primary protection mechanism against strong light, it could not block the excessive inflow of light energy under the CCT $0 \%$ treatment for a long time, and it affected the overall photoreaction process. Phalaenopsis "Edessa", a CAM plant belonging to Orchidaceae, showed a similar overall energy flow pattern under drought stress [25]. The decrease in ABS/RC, TRo/RC, $\mathrm{ETo} / \mathrm{RC}$, and DIo/RC observed around day 79 after treatment was presumed to be a process of gradually recovering the decrease in efficiency due to stress as the sun's radiation decreased over time (Figure $4 a-d)$. 
REo/RC shows the electron transport energy flow to photosystem I [23], showing a similar trend to TRo/RC and ETo/RC (Figure 4e). Additionally, the overall photosynthetic activity was low in the control $90 \%$ treatment samples due to excessively low light condition without the appropriate temperature condition required for metabolic activity. It can be recovered when sufficient light energy is supplied again. From the relatively high REo/TRo, it is expected that the reaction of transferring the light energy captured in photosystem II to photosystem I was relatively efficient (Figure 4f).

In the case of the control samples, $\Psi_{O}$ did not considerably change on days 21,56 , and 77 after treatment, whereas $\Phi_{\mathrm{PO}}$ and $\Phi_{\mathrm{EO}}$ slightly increased as the shading rate increased (Figure 5a). $\Phi_{\mathrm{PO}}$ indicates the maximum quantum yield in the initial photochemical reaction, and $\Phi_{\mathrm{EO}}$ shows the quantum yield of electron transport after $\mathrm{Q}_{\mathrm{A}^{-}}$, the primary electron acceptor in photosystem II [23]. Thus, it was possible to know that the electron transport efficiency increased due to the shading treatment. However, some indices of the CCT samples showed relatively large differences around day 56 after treatment. In the CCT $0 \%$ treatment, $\Phi_{\mathrm{PO}}$ decreased by $38 \%$ and $\Phi_{\mathrm{EO}}$ decreased by $40 \%$ compared to the control $0 \%$ treatment. In contrast, $\mathrm{V}_{\mathrm{k}}$ increased by $38 \%$ (Figure 5). Although the other indices of the CCT $60 \%$ treatment did not show a large difference, $\mathrm{V}_{\mathrm{k}}$ increased by approximately $50 \%$. The increase in $V_{k}$ indicated that electron transfer was inhibited by the deactivation of the oxygen-evolving complex after the $\mathrm{Q}_{\mathrm{A}}{ }^{-}$in photosystem II [24]. After 77 days, the control samples showed a similar tendency to that observed around day 56 according to the shading rate, whereas the decrease in $\Phi_{\mathrm{PO}}$ and $\Phi_{\mathrm{EO}}$ and the increase in $\mathrm{V}_{\mathrm{k}}$ in the CCT $0 \%$ treatment were much greater than those observed on day 56 (Figure 5). These results revealed that the overall electron transfer efficiency was inhibited due to the decrease in $\Phi_{\mathrm{PO}}$ and $\Phi_{\mathrm{EO}}$ and the increase in $\mathrm{V}_{\mathrm{k}}$ in the CCT compared to the control samples, and the shading treatment slightly improved this tendency.

The activity of photosystem II of $S$. japonica was observed according to climate change conditions using chlorophyll fluorescence analysis (Figure 6). $\mathrm{PI}_{\mathrm{ABS}}$ and $\mathrm{DF}_{\mathrm{ABS}}$, the vitality indices of the photosynthetic apparatus, greatly increased with a higher shading rate in both the control and CCT samples [23]. $\mathrm{PI}_{\mathrm{ABS}}$ refers to the energy conservation efficiency in the process of reducing electron carriers by using absorbed light energy, and $\mathrm{DF}_{\mathrm{ABS}}$ indicates the momentum in the electron transport process [25-27]. $\mathrm{PI}_{\mathrm{ABS}}$ and $\mathrm{DF}_{\mathrm{ABS}}$ in S. japonica around day 35 after treatment tended to be control $90 \%>$ control $60 \%>$ CCT $90 \%>$ control $0 \% \geqq$ CCT $60 \%>$ CCT $0 \%$. In particular, a distinct decrease was observed in CCT $0 \%$ treatment (Figure 6 ). The result showing a drastic decrease in the overall activity of photosystem II, such as energy conservation efficiency and momentum, in the electron transfer process can be understood as a photoinhibition that occurs when growing in a strong light environment for a long time. It was distinct when the atmospheric $\mathrm{CO}_{2}$ concentration and temperature were relatively high.

Additionally, it is believed that when it grows under insufficient light condition due to shading treatment, an adaptive reaction appears to process light energy more efficiently by increasing the activity of photosystem II, such as $\mathrm{PI}_{\mathrm{ABS}}$ and $\mathrm{DF}_{\mathrm{ABS}}$. The control samples showed a higher tendency than the CCT, indicating a relatively sensitive response. Phalaenopsis "Edessa" also showed that plants growing in low light condition had higher $\mathrm{PI}_{\mathrm{ABS}}[25]$. 

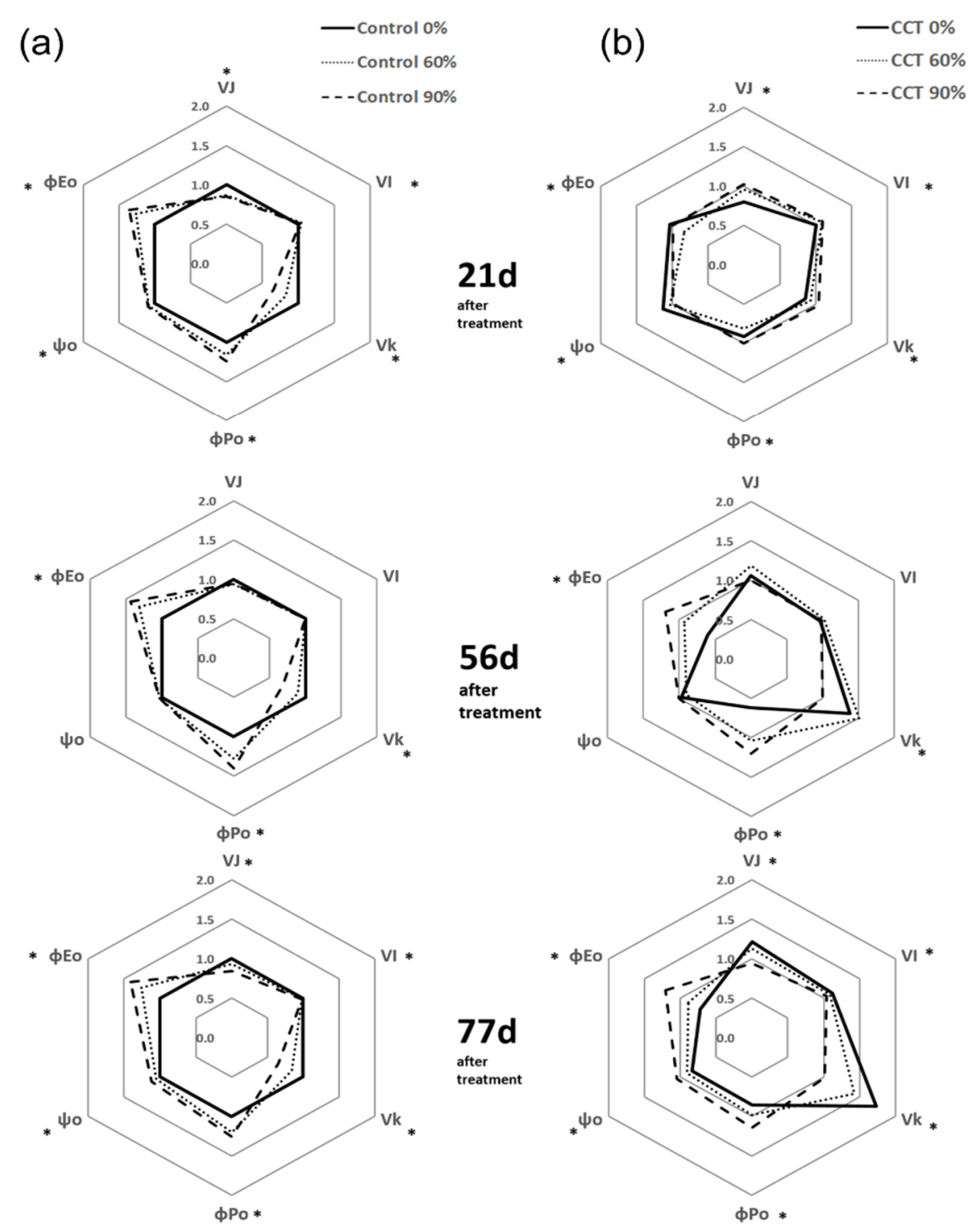

Figure 5. Radar plots of several fluorescence parameters (VJ, VI, Vk, $\Phi P O, \Phi E O$, and $\Psi \mathrm{O}$ ) of Sedirea japonica under control $\left(\mathrm{CO}_{2}=400 \mathrm{ppm}\right.$ ) (a) and CCT (climate change treatment, $\mathrm{CO}_{2}=650 \mathrm{ppm}$, temperature $=$ control $\left.+3{ }^{\circ} \mathrm{C}\right)(\mathbf{b})$ conditions 21,56 , and 77 days after the treatment. The asterisk indicates significance at $p<0.05$.

\subsection{Chlorophyll and Carotenoid Contents}

The chlorophyll content of $S$. japonica tended to increase as the shading rate increased $(p<0.05)$. The CCT samples tended to show lower values than the control under the same shading conditions (Table 1). However, the interaction between climate change conditions and shading treatment was not significant $(p>0.05)$. 
(a)

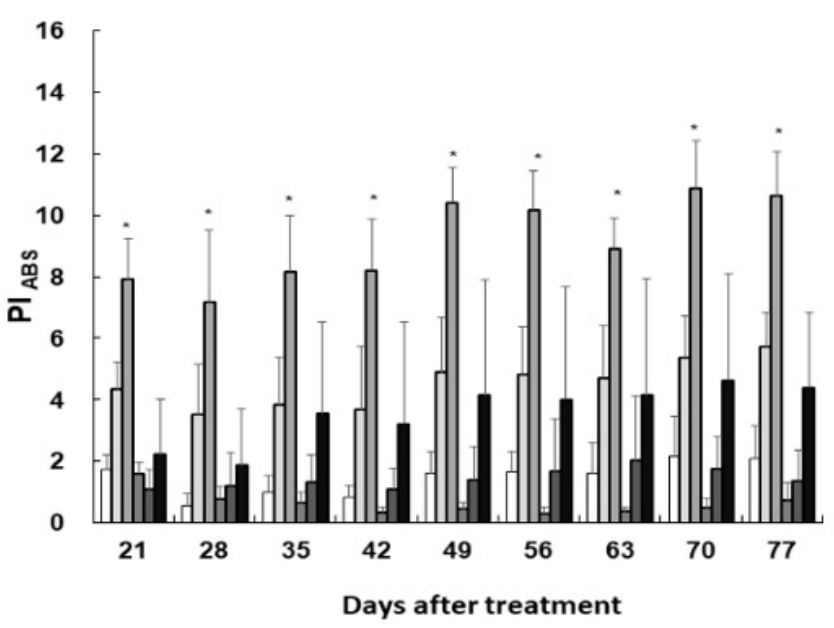

(b)
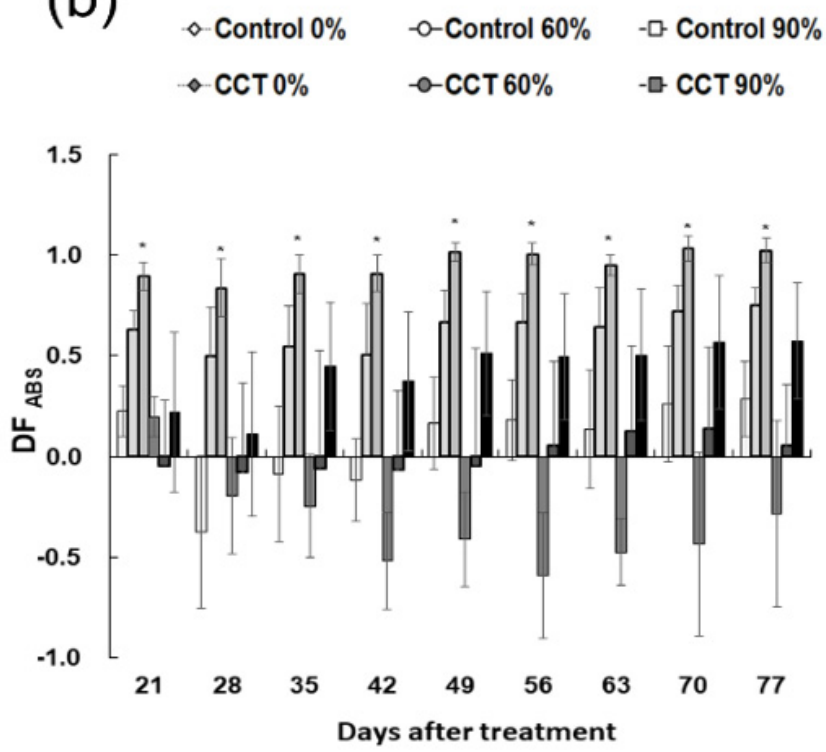

Figure 6. Effects of shading level on PI ABS (a) and DF ABS (b) of Sedirea japonica under control $\left(\mathrm{CO}_{2}=400 \mathrm{ppm}\right)$ and CCT (climate change treatment, $\mathrm{CO}_{2}=650 \mathrm{ppm}$, temperature $=$ control $+3{ }^{\circ} \mathrm{C}$ ) conditions. Vertical bars are mean $\pm \mathrm{SD}(n=5)$. The asterisk indicates significance at $p<0.05$.

Table 1. Effects of shading level on chlorophyll and carotenoid contents of Sedirea japonica under control $\left(\mathrm{CO}_{2}=400 \mathrm{ppm}\right)$ and CCT (climate change treatment, $\mathrm{CO}_{2}=650 \mathrm{ppm}$, temperature $=$ control $+3^{\circ} \mathrm{C}$ ) conditions.

\begin{tabular}{|c|c|c|c|c|c|c|}
\hline \multirow{2}{*}{ Treatment } & \multicolumn{3}{|c|}{ Chlorophyll Content $\left(\mathrm{mg} \mathrm{g}^{-1}\right)$} & \multirow{2}{*}{$\begin{array}{c}\text { Carotenoid } \\
\text { Content }\left(\mathrm{mg} \mathrm{g}^{-1}\right)\end{array}$} & \multirow{2}{*}{ Chl a/b } & \multirow{2}{*}{ T chl/Car } \\
\hline & a & b & $a+b$ & & & \\
\hline Control $0 \%$ & $2.95 \pm 0.36$ & $0.60 \pm 0.13$ & $3.55 \pm 0.49$ & $1.17 \pm 0.12$ & $4.99 \pm 0.58$ & $3.02 \pm 0.15$ \\
\hline Control $60 \%$ & $4.12 \pm 0.81$ & $1.26 \pm 0.17$ & $5.37 \pm 0.66$ & $1.40 \pm 0.20$ & $3.38 \pm 1.06$ & $3.86 \pm 0.07$ \\
\hline Control 90\% & $6.10 \pm 0.52$ & $1.35 \pm 0.22$ & $7.44 \pm 0.64$ & $1.66 \pm 0.11$ & $4.60 \pm 0.82$ & $4.48 \pm 0.32$ \\
\hline ССТ $0 \%$ & $2.86 \pm 0.40$ & $0.60 \pm 0.04$ & $3.46 \pm 0.40$ & $1.09 \pm 0.19$ & $4.81 \pm 0.76$ & $3.19 \pm 0.22$ \\
\hline CCT $60 \%$ & $4.26 \pm 0.46$ & $1.00 \pm 0.18$ & $5.26 \pm 0.59$ & $1.25 \pm 0.14$ & $4.29 \pm 0.50$ & $4.20 \pm 0.26$ \\
\hline ССТ $90 \%$ & $5.62 \pm 0.07$ & $1.41 \pm 0.03$ & $7.03 \pm 0.10$ & $1.56 \pm 0.04$ & $3.99 \pm 0.09$ & $4.53 \pm 0.05$ \\
\hline CCT & ns & ns & ns & * & ns & * \\
\hline Shading & $* *$ & $* *$ & $* *$ & $* *$ & * & $* *$ \\
\hline $\mathrm{CCT} \times$ Shading & $\mathrm{ns}$ & ns & ns & $\mathrm{ns}$ & ns & ns \\
\hline
\end{tabular}

Each value is expressed as the mean $\pm \mathrm{SD}(n=5) .{ }^{*} p \leq 0.05,{ }^{* *} p \leq 0.001$, and ns: non-significance. CCT: climate change treatment, Chl a: chlorophyll a, Chl b: chlorophyll b, and T chl: total chlorophyll content.

In general, as an adaptation to absorb more light under low light condition, the increase in chlorophyll $b$ constituting the light-harvesting chl-protein complex is generally larger than the increase in chlorophyll a, which is mainly bound to the reaction center; therefore, chlorophyll $\mathrm{a} / \mathrm{b}$ tends to decrease [28,29]; S. japonica generally showed the same tendency, except for control $60 \%$ treatment (Table 1). In other words, it can be understood as an adaptation process of increasing the antenna pigment to increase the light-receiving rate and the efficiency of using light while growing in a relatively insufficient light environment $[30,31]$. For $0 \%$ and $90 \%$ shading treatments, the chlorophyll $\mathrm{a} / \mathrm{b}$ of the CCT samples tended to be lower than that of the controls. This was due to the difference in the decrease in chlorophyll a, and it could decrease the activity of the carbon fixation system [32].

Carotenoids perform a photoprotective function that quickly eliminates the excited state of chlorophyll under stress conditions such as strong light environments [33]. However, carotenoid content increased with a higher shading rate for S. japonica (Table 1). This is 
believed to be because carotenoids acted more as an auxiliary pigment rather than focusing on the photoprotective function.

\subsection{Growth Characteristics}

The number and thickness of $S$. japonica leaves were not significantly different $(p>0.05)$. Leaf dry weight, leaf area, SLA, and LAR were significantly different among the shading treatments $(p<0.05)$. The increase in leaf dry weight, leaf area, and shading rate could be understood as a general reaction to increasing the efficiency of using light (Table 2). Moreover, root dry weight, total dry weight, $\mathrm{T} / \mathrm{R}$ ratio, SLA, LAR, and LWR were significantly different among climate change conditions $(p<0.05)$. However, the interaction between climate change conditions and shading was not significant $(p>0.05)$.

For the leaf thickness of the control samples, the $0 \%$ shading treatment tended to be lower than that of the $60 \%$ and $90 \%$ shading treatments, which is considered to be because the leaf growth of the $0 \%$ shading treatment was relatively lower compared to the $60 \%$ and $90 \%$ shading treatments, so no significant features were revealed.

For many CAM plants, the development of vacuoles, storing malate in a high $\mathrm{CO}_{2}$ concentration environment, can affect $\mathrm{CO}_{2}$ uptake [34]. Cui et al. [21] reported that the overall plant size and thickness increased as they became more succulent. This trend was not observed in S. japonica (Table 2). Phalaenopsis (Doritaenopsis Queen Beer 'Mantefon'), a plant similar to $S$. japonica, also did not show the development of leaf thickness [22].

The dry weight of $S$. japonica was lower in the CCT than in the control samples. In particular, root dry weight showed a large difference to have a great influence on the $T / R$ ratio and the total dry weight (Table 2). These results were different from the generally known trends. Drennan and Nobel [10] reported that 10 CAM plants, including $A$. deserti, had higher biomass and $\mathrm{CO}_{2}$ uptake in a high $\mathrm{CO}_{2}$ environment (more than double of the control). It is known that $\mathrm{C} 3$ and $\mathrm{C} 4$ plants often show carbon fertilization effects under high atmospheric $\mathrm{CO}_{2}$ conditions $[8,9,35]$. However, the biomass of some plants, including A. comosus [36], slightly decreased in high $\mathrm{CO}_{2}$ concentration environments, indicating that there are differences in adaptation between species. Kim et al. [37] reported that Phalaenopsis "Fuller's Pink Swallow" did not show a significant difference in shoot biomass and dry weight when $\mathrm{CO}_{2}$ concentration was increased from 450 to $800 \mathrm{ppm}$; root dry weight was also not different (1.92 g and $1.96 \mathrm{~g}$, respectively).

The decrease in the overall growth of $S$. japonica even under increased atmospheric $\mathrm{CO}_{2}$ concentration could be highly related to the difference in $\mathrm{CO}_{2}$ uptake (Table 2). It is believed that material consumption increased due to respiration because atmospheric temperature $\left(\geq 3{ }^{\circ} \mathrm{C}\right)$, as well as atmospheric $\mathrm{CO}_{2}$ concentration, was increased in this study, unlike previous studies, which mainly increased the atmospheric $\mathrm{CO}_{2}$ concentration. In other words, it can be considered that stomatal closure to reduce loss of moisture in response to relatively high temperature reduced $\mathrm{CO}_{2}$ fixation and increased consumption due to respiration, leading to a decrease in overall growth. Increased atmospheric $\mathrm{CO}_{2}$ concentration and temperature-induced water stress to Populus alba $\times$ glandulosa, a C3 plant, and a decrease in the activities of the photochemical and carbon fixation systems due to this resulted in a decrease in photosynthetic capacity and growth rate [32]. The growth of yellow rose mallow, an endangered species just like $S$. japonica, would be limited by the amount of light in higher atmospheric $\mathrm{CO}_{2}$ concentration and temperature conditions [5].

These results indicated that increased atmospheric $\mathrm{CO}_{2}$ concentration and temperature should be considered to evaluate the ecological adaptation of plants to climate change and global warming. It can be assumed that a response to reduce water loss and an increase in respiration can offset the benefit of carbon fertilization. 


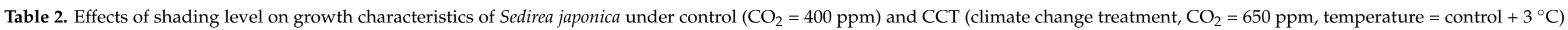
conditions.

\begin{tabular}{|c|c|c|c|c|c|c|c|c|c|c|}
\hline \multirow{2}{*}{ Treatment } & \multirow{2}{*}{ No. of Leaves } & \multicolumn{3}{|c|}{ Dry Mass Production (g) } & \multirow{2}{*}{$\begin{array}{c}\text { Leaf Thickness } \\
(\mathrm{mm})\end{array}$} & \multirow{2}{*}{$\begin{array}{c}\text { Leaf Area } \\
\left(\mathrm{cm}^{2}\right)\end{array}$} & \multirow{2}{*}{$\begin{array}{c}\text { T/R Ratio } \\
\quad\left(\mathrm{g} \mathrm{g}^{-1}\right)\end{array}$} & \multirow{2}{*}{$\begin{array}{c}\text { SLA } \\
\left(\mathrm{cm}^{2} \mathrm{~g}^{-1}\right)\end{array}$} & \multirow{2}{*}{$\begin{array}{c}\text { LAR } \\
\left(\mathrm{g} \mathrm{g}^{-1}\right)\end{array}$} & \multirow{2}{*}{$\begin{array}{c}\text { LWR } \\
\left(g^{-1}\right)\end{array}$} \\
\hline & & Leaf & Root & Total & & & & & & \\
\hline Control $0 \%$ & $4.6 \pm 1.3$ & $0.22 \pm 0.09$ & $0.32 \pm 0.1$ & $0.54 \pm 0.19$ & $1.50 \pm 0.11$ & $39.6 \pm 15.8$ & $0.66 \pm 0.14$ & $187.5 \pm 29.6$ & $73.0 \pm 6.6$ & $0.39 \pm 0.05$ \\
\hline Control $60 \%$ & $5.0 \pm 1.0$ & $0.31 \pm 0.05$ & $0.40 \pm 0.09$ & $0.72 \pm 0.13$ & $1.65 \pm 0.08$ & $59.8 \pm 6.8$ & $0.80 \pm 0.12$ & $191.1 \pm 13$ & $85.0 \pm 12.1$ & $0.44 \pm 0.04$ \\
\hline Control 90\% & $5.6 \pm 1.1$ & $0.33 \pm 0.06$ & $0.39 \pm 0.03$ & $0.72 \pm 0.08$ & $1.63 \pm 0.12$ & $68.9 \pm 8.1$ & $0.87 \pm 0.12$ & $207.6 \pm 15.5$ & $95.9 \pm 7.5$ & $0.46 \pm 0.03$ \\
\hline ССТ $0 \%$ & $4.6 \pm 0.6$ & $0.22 \pm 0.09$ & $0.24 \pm 0.10$ & $0.46 \pm 0.19$ & $1.64 \pm 0.11$ & $45.3 \pm 12.9$ & $0.96 \pm 0.14$ & $211.1 \pm 24.7$ & $103.2 \pm 16.6$ & $0.49 \pm 0.03$ \\
\hline ССТ $60 \%$ & $4.4 \pm 0.9$ & $0.23 \pm 0.05$ & $0.23 \pm 0.04$ & $0.46 \pm 0.09$ & $1.61 \pm 0.11$ & $53.5 \pm 6.7$ & $0.98 \pm 0.06$ & $239.5 \pm 28.7$ & $118.0 \pm 11.5$ & $0.50 \pm 0.02$ \\
\hline ССТ $90 \%$ & $4.4 \pm 0.9$ & $0.27 \pm 0.08$ & $0.27 \pm 0.06$ & $0.53 \pm 0.14$ & $1.58 \pm 0.05$ & $64.0 \pm 15.9$ & $0.99 \pm 0.08$ & $242 \pm 13.9$ & $120.2 \pm 4.3$ & $0.50 \pm 0.02$ \\
\hline Shading & ns & * & ns & ns & ns & $* *$ & ns & * & * & ns \\
\hline $\mathrm{CCT} \times$ Shading & ns & ns & ns & ns & ns & ns & ns & ns & ns & ns \\
\hline
\end{tabular}

Each value is expressed as the mean $\pm \mathrm{SD}(n=5) .{ }^{*} p \leq 0.05,{ }^{* *} p \leq 0.001$, and ns: non-significance. 


\section{Materials and Methods}

\subsection{Materials and Experimental Design}

In this study, 100 S. japonica samples proliferated via tissue culture at the Research Center for Endangered Species of the National Institute of Ecology in 2020 were used. Each S. japonica sample was placed at the center of a 10-cm diameter pot filled with moss. The samples were carefully grown and bottom irrigation was used to prevent drying of the moss.

The study was conducted in soil-plant daylight system (SPDS) chambers at the Climate Change Education Center of the Korea National College of Agriculture and Fisheries to provide atmospheric $\mathrm{CO}_{2}$ concentration and temperature conditions according to the climate change scenario. The experiment was conducted from 24 August to 13 November 2020, while performing periodic observations.

The samples were divided into control and climate change treatments (CCT) according to the $\mathrm{RCP} 6.0$ scenario. The control samples were maintained under $\mathrm{CO}_{2}$ concentration of $400 \mathrm{ppm}$, and the temperature inside the chamber was periodically modified according to the meteorological conditions in Jeonju in the past 3 years. For the CCT samples, $\mathrm{CO}_{2}$ concentration was maintained at $650 \mathrm{ppm}$, and the temperature inside the chamber was maintained as that used for the control $+3^{\circ} \mathrm{C}$. Moreover, a shade was installed to provide no shading, $60 \%$ shading, and $90 \%$ shading treatments in both the control and CCT chambers, and the light was measured intensity using a photo-radiometer (HD 2102.1, Delta OHM, Italy) on midday of 20 August, which showed $2062 \pm 125 \mu \mathrm{mol} \mathrm{m}^{-2} \mathrm{~s}^{-1}$ in the control, $863 \pm 74 \mu \mathrm{mol} \mathrm{m}{ }^{-2} \mathrm{~s}^{-1}$ in the $60 \%$ shading, and $179 \pm 52 \mu \mathrm{mol} \mathrm{m}^{-2} \mathrm{~s}^{-1}$ in the $90 \%$ shading $(n=10)$. Then, 10 samples were placed for each treatment to examine the growth and physiological response of $S$. japonica under different light conditions in the climate change scenario. The changes in temperature and relative humidity were monitored using the meteorological observation sensor installed in the chamber, and the internal environment due to the shading treatment was investigated thrice at around 12 p.m. on 15 September using a portable photometer and temperature and humidity meter.

\subsection{Daily Changes in $\mathrm{CO}_{2}$ Absorption Rate and Stomatal Response}

The $\mathrm{CO}_{2}$ absorption rate of $S$. japonica by climate change condition was investigated for the control samples and those grown under non-shading CCT conditions. The $\mathrm{CO}_{2} \mathrm{ex}-$ change rate and stomatal conductance $\left(\mathrm{g}_{\mathrm{s}}\right)$ were measured using a portable photosynthesis system (Li-6800, Li-Cor Inc., Lincoln, NE, USA), with three replicate plants in each treatment from 4 p.m. to 8 a.m. from 13 November to 30 November. During the measurements, ambient light was provided using the clear-top leaf chamber (6800-12A, Li-Cor Inc., Lincoln, NE, USA), and photosynthetic photon flux density has been measured concurrently, showing the values of $140 \sim 250 \mu \mathrm{mol} \mathrm{m}^{-2} \mathrm{~s}^{-1}$ (4 p.m. to 7 p.m.) and $0 \sim 8 \mu \mathrm{mol} \mathrm{m}{ }^{-2} \mathrm{~s}^{-1}$ (7 p.m. to 6 a.m.). Moreover, $\mathrm{CO}_{2}$ uptake, intrinsic water use efficiency (WUE $\mathrm{F}_{\mathrm{i}}$ ), and instantaneous transpiration efficiency (ITE) at night (7 p.m. to 6 a.m.; 12 h) were calculated from the measurement $[22,38,39]$. For the measurement, relative humidity was $60 \%$, the amount of air inflow into the chamber was $600 \mu \mathrm{mols}^{-1}$, and $\mathrm{CO}_{2}$ concentration was 400 and $650 \mathrm{ppm}$ based on the mean concentration of each treatment. The leaf temperature was set at $25^{\circ} \mathrm{C}$ for the control and $28^{\circ} \mathrm{C}$ for the treatment samples.

\subsection{Chlorophyll Fluorescence Response}

Chlorophyll fluorescence response was evaluated using polyphasic increase in chlorophyll a fluorescence transients (OKJIP) analysis at 1-week intervals from day 21 after initiating the shading treatment and CCT. Dark-adapted leaves were irradiated with $3500 \mu \mathrm{mol} \mathrm{m}^{-2} \mathrm{~s}^{-1}$ light for $20 \mathrm{~min}$ using a Plant Efficiency Analyzer (Hansatech Instrument Ltd., King's Lynn, England), and chlorophyll fluorescence densities were measured at $50 \mu \mathrm{s}$ (O stage), $300 \mu \mathrm{s}$ (K stage), $2 \mathrm{~ms}$ (J stage), $30 \mathrm{~ms}$ (I stage), and $500 \mathrm{~ms}$ (P stage). All leaf measurements were done using the uppermost mature leaf of each of the five replicate plants. Biophysical parameters $\left(\mathrm{V}_{\mathrm{J}}, \mathrm{V}_{\mathrm{I}}, \mathrm{V}_{\mathrm{k}}, \Phi_{\mathrm{PO}}, \Phi_{\mathrm{EO}}, \Psi_{\mathrm{O}}, \mathrm{ABS} / \mathrm{RC}, \mathrm{DIo} / \mathrm{RC}, \mathrm{TRo} / \mathrm{RC}\right.$, 
$\mathrm{ETo} / \mathrm{RC}, \mathrm{RE}_{0} / \mathrm{RC}, \mathrm{RE}_{0} / \mathrm{TR}_{0}, \mathrm{PI}_{\mathrm{ABS}}$, and $\mathrm{DF}_{\mathrm{ABS}}$; Table 3) were calculated from the results of OKJIP analysis $[23,24]$.

\subsection{Chlorophyll and Carotenoid Contents}

After completing all physiological response tests, three leaves were randomly collected from each treatment, and $0.1 \mathrm{~g}$ of the leaf blade was placed in a $20 \mathrm{~mL}$ glass bottle containing $10 \mathrm{~mL}$ of dimethyl sulfoxide solution. The pigments were extracted for $6 \mathrm{~h}$ in a thermostat set at $60{ }^{\circ} \mathrm{C}$ [40]. The absorbance of the solution was measured at wavelengths of 663,645 , and $470 \mathrm{~nm}$ using a UV/VIS spectrophotometer (HP 8453, Hewlett-Packard, New York, NY, USA) to estimate chlorophyll $a, b, a+b$, and carotenoid contents [41,42].

Table 3. Summary of chlorophyll fluorescence parameters from OKJIP test.

\begin{tabular}{|c|c|}
\hline Parameters & Description \\
\hline $\mathrm{V}_{\mathrm{J}}$ & Relative variable fluorescence at the J-step \\
\hline $\mathrm{V}_{\mathrm{I}}$ & Relative variable fluorescence at the I-step \\
\hline $\mathrm{V}_{\mathrm{k}}$ & Relative variable fluorescence at the k-step \\
\hline$\Phi_{\mathrm{PO}}(=\mathrm{TRo} / \mathrm{ABS})$ & Probability that an absorbed photon leads to reduction further than $\mathrm{Q}_{\mathrm{A}}{ }^{-}$ \\
\hline$\Phi_{\mathrm{EO}}(=\mathrm{ETo} / \mathrm{ABS})$ & $\begin{array}{c}\text { Probability that an absorbed photon leads to electron transport further } \\
\text { than } Q_{\mathrm{A}^{-}}\end{array}$ \\
\hline$\Psi_{\mathrm{O}}(=\mathrm{ETo} / \mathrm{TRo})$ & Probability that an absorbed photon leads to reduction of $\mathrm{Q}_{\mathrm{A}}^{-}$ \\
\hline $\mathrm{ABS} / \mathrm{RC}$ & Absorption flux per reaction center \\
\hline $\mathrm{TR}_{0} / \mathrm{RC}$ & Trapped energy flux per reaction center \\
\hline $\mathrm{ET}_{0} / \mathrm{RC}$ & Electron transport flux from QA to QB per reaction center \\
\hline $\mathrm{DI}_{0} / \mathrm{RC}$ & Energy dissipation flux per reaction center \\
\hline $\mathrm{RE}_{0} / \mathrm{RC}$ & Electron transport flux until PSI acceptors per reaction center \\
\hline $\mathrm{RE}_{0} / \mathrm{TR}_{0}$ & $\begin{array}{l}\text { Efficiency with which a trapped exciton can move an electron into the } \\
\text { electron transport chain from QA-to the PSI end electron acceptors }\end{array}$ \\
\hline $\mathrm{PI}_{\mathrm{ABS}}$ & Performance index on absorption basis. \\
\hline $\mathrm{DF}_{\mathrm{ABS}}$ & Driving force on absorption basis. \\
\hline
\end{tabular}

\subsection{Growth Characteristics}

After evaluating all the physiological responses, the number of leaves, leaf thickness, leaf area, leaf dry weight, and root dry weight were measured. Leaf thickness was measured at the utmost center of the leaf using Vernier calipers, and the dry weight was measured after drying the leaf at $80{ }^{\circ} \mathrm{C}$ for $48 \mathrm{~h}$ in a dryer (DS-80-5, Dasol Scientific Co. Ltd., Gyeonggido, Korea). Thereafter, tree/root ratio (T/R ratio), specific leaf area (SLA), leaf area ratio (LAR), and leaf weight ratio (LWR) were calculated. One-way analysis of variance (ANOVA) was performed for the $\mathrm{CO}_{2}$ exchange rate and chlorophyll fluorescence response by leaf temperature, and the significance among each treatment was determined at $5 \%$ (Duncan's multiple range test). The relation among chlorophyll content, carotenoid content, and growth response effects due to climate change and photoenvironment was assessed using two-way ANOVA. SPSS Statistics Program (Version 19.0) was used for all statistical analyses.

\section{Conclusions}

S. japonica showed characteristics that are typical of CAM plants that fix $\mathrm{CO}_{2}$ at night. As the shading rate increased, the chlorophyll $a, b, a+b$, and carotenoid content, the leaf area, and the leaf dry weight increased to absorb and use light efficiently. Moreover, the CCT samples showed a lower $\mathrm{CO}_{2}$ absorption rate, $\mathrm{CO}_{2}$ uptake, stomatal conductance, and biomass growth and a higher water utilization efficiency than the control. This could be because of stomatal closure in the CCT to reduce water loss due to a relatively higher temperature condition, which reduced $\mathrm{CO}_{2}$ fixation and increased consumption due to respiration, which could inhibit the overall growth. In particular, the CCT $\%$ treatment revealed a dynamic photoinhibition phenomenon showing a significant increase in ABS/RC, $\mathrm{TRo} / \mathrm{RC}, \mathrm{ETo} / \mathrm{RC}$, and DIo/RC and a decrease in $\mathrm{PI}_{\mathrm{ABS}}$ and $\mathrm{DF}_{\mathrm{ABS}}$. Furthermore, the 
leaf dry weight, root dry weight, total dry weight, chlorophyll content, and carotenoid content were the worst growth indices. In conclusion, the RCP 6.0 condition that increases atmospheric $\mathrm{CO}_{2}$ concentration and temperature at the same time requires $60 \%$ or $90 \%$ shading treatment, and no shading provides the least favorable growth condition.

Author Contributions: Conceptualization, K.C.L., J.A. and N.Y.K.; data curation, K.C.L.; methodology, K.C.L.; resources, J.E.H. and J.A.; writing-original draft, K.C.L.; writing-review and editing, J.A., J.E.H., P.B.K., H.B.P., S.K., H.J.P., C.W.L. and B.-D.L.; funding acquisition, N.Y.K. All authors have read and agreed to the published version of the manuscript.

Funding: This study was carried out with the support of 'Individual adaptation and ecological environmental change monitoring in the restoration target site (Project No. NIE-C-2021-49) provided by National Institute of Ecology.

Data Availability Statement: Data is contained within the article.

Conflicts of Interest: The authors declare no conflict of interest.

\section{References}

1. Kim, Y.K.; Jo, S.J.; Kim, K.J. Phylogenetic position of Neofinetia and Sedirea (Orchidaceae) and their species identification using the chloroplast matK and the nuclear ITS sequences. Korean J. Plant Taxon. 2014, 44, 39-50. [CrossRef]

2. Suetsugu, K.; Tanaka, K. Pollination of Sedirea japonica (Orchidaceae) by Bombus diversus diversus (Hymenoptera: Apidae). Eur. J. Entomol. 2013, 110, 545. [CrossRef]

3. Shim, Y.J.; Park, Y.S.; Jang, R.H.; Yoon, Y.J.; Kim, S.R.; Han, S.H. The development of Habitat Suitability Index Model of Class I endangered wildlife, Sedirea japonica. J. Korean Isl. 2020, 32, 153-172. [CrossRef]

4. IPCC (Intergovernmental Panel on Climate Change). Climate Change 2014: Synthesis Report. Contribution of Working Group I, II and III to the Fifth Assessment Report of the Intergovernmental Panel on Climate Change; IPCC: Geneva, Switzerland, $2014 ;$ pp. 1-151.

5. Lee, S.I.; Lee, E.P.; Kim, E.J.; Park, J.H.; Cho, K.T.; Lee, S.Y.; You, Y.H. Growth response and variation of ecological niche breadth of Hibiscus hamabo, the endangered plant, according to light, moisture and nutrient under elevated $\mathrm{CO}_{2}$ concentration and temperature. Korean J. Environ. Ecol. 2017, 31, 279-286. [CrossRef]

6. Newth, D.; Gunasekera, D. Projected changes in wet-bulb globe temperature under alternative climate scenarios. Atmosphere 2018, 9, 187. [CrossRef]

7. Korea Meteorological Administration. Analysis of Climate Change Forecasts on the Korean Peninsula; Korea Meteorological Adiminstration: Seoul, Korea, 2018; p. 16.

8. Norby, R.J.; Wullschleger, S.D.; Gunderson, C.A.; Nietch, C.T. Increased growth efficiency of Quercus alba trees in a $\mathrm{CO}_{2}$-enriched atmosphere. New Phytol. 1995, 131, 91-97. [CrossRef]

9. Huang, J.G.; Bergeron, Y.; Denneler, B.; Berninger, F.; Tardif, J. Response of forest trees to increased atmospheric $\mathrm{CO}_{2}$. $\mathrm{CRC} C \mathrm{Crit}$. Rev. Plant Sci. 2007, 26, 265-283. [CrossRef]

10. Drennan, P.M.; Nobel, P.S. Responses of CAM species to increasing atmospheric $\mathrm{CO}_{2}$ concentrations. Plant Cell Environ. 2000, 23, 767-781. [CrossRef]

11. Zhu, P.; Zhuang, Q.; Ciais, P.; Welp, L.; Li, W.; Xin, Q. Elevated atmospheric $\mathrm{CO}_{2}$ negatively impacts photosynthesis through radiative forcing and physiology mediated climate feedback. Geophys. Res. Lett. 2017, 44, 1956-1963. [CrossRef]

12. Osmond, C.B. Crassulacean acid metabolism: A curiosity in context. Annu. Rev. Plant Physiol. 1978, 29, 379-414. [CrossRef]

13. Hopkins, W.G.; Hüner, N.P.A. Introduction to Plant Physiology, 4th ed.; John Wiley and Sons: New York, NY, USA, 2008; pp. 223-230.

14. Zhu, J.; Goldstein, G.; Bartholomew, D.P. Gas exchange and carbon isotope composition of Ananas comosus in response to elevated $\mathrm{CO}_{2}$ and temperature. Plant Cell Environ. 1999, 22, 999-1007. [CrossRef]

15. Nobel, P.S.; Israel, A.A.; Wang, N. Growth, $\mathrm{CO}_{2}$ uptake, and responses of the carboxylating enzymes to inorganic carbon in two highly productive CAM species at current and doubled $\mathrm{CO}_{2}$ concentrations. Plant Cell Environ. 1996, 19, 585-592. [CrossRef]

16. Hogewoning, S.W.; van den Boogaart, S.A.; van Tongerlo, E.; Trouwborst, G. CAM-physiology and carbon gain of the orchid Phalaenopsis in response to light intensity, light integral and $\mathrm{CO}_{2}$. Plant Cell Environ. 2021, 44, 762-774. [CrossRef] [PubMed]

17. Winter, K.; Smith, J.A.C. Crassulacean acid metabolism: Current status and perspectives. In Crassulacean Acid Metabolism; Ecological studies (analysis and synthesis); Winter, K., Smith, J.A.C., Eds.; Springer: Berlin/Heidelberg, Germany, 1996; pp. 230-246.

18. Huerta, A.J.; Ting, I.P. Effects of various levels of $\mathrm{CO}_{2}$ on the induction of Crassulacean acid metabolism in Portulacaria afra (L.) Jacq. Plant Physiol. 1988, 88, 183-188. [CrossRef]

19. Winter, K.; Zotz, G.; Baur, B.; Dietz, K.J. Light and dark $\mathrm{CO}_{2}$ fixation in Clusia uvitana and the effects of plant water status and $\mathrm{CO}_{2}$ availability. Oecologia 1992, 91, 47-51. [CrossRef]

20. Graham, E.A.; Nobel, P.S. Long-term effects of a doubled atmospheric $\mathrm{CO}_{2}$ concentration on the CAM species Agave Deserti. J. Exp. Bot. 1996, 47, 61-69. [CrossRef] 
21. Cui, M.; Miller, P.M.; Nobel, P.S. $\mathrm{CO}_{2}$ exchange and growth of the Crassulacean acid metabolism plant Opuntia ficus-indica under elevated $\mathrm{CO}_{2}$ in open-top chambers. Plant Physiol. 1993, 103, 519-524. [CrossRef]

22. Lim, N.H.; Lee, H.B.; An, S.K.; Kim, K.S. Acclimation of young Doritaenopsis Queen Beer 'Mantefon' plants under increased $\mathrm{CO}_{2}$ concentration. Flower Res. J. 2018, 26, 11-18. [CrossRef]

23. Strasser, R.J.; Srivastava, A.; Tsimilli-Michael, M. The fluorescence transient as a tool to characterize and screen photosynthetic samples. In Probing Photosynthesis: Mechanism, Regulation and Adaptation; Yunus, M., Pathre, U., Mohanty, P., Eds.; Taylor and Francis: London, UK; New York, NY, USA, 2000; pp. 445-483.

24. Wang, Z.X.; Chen, L.; Ai, J.; Qin, H.Y.; Liu, Y.X.; Xu, P.L.; Jiao, Z.Q.; Zhao, Y.; Zhang, Q.T. Photosynthesis and activity of photosystem II in response to drought stress in amur grape (Vitis amurensis Rupr.). Photosynthetica 2012, 50, 189-196. [CrossRef]

25. Ceusters, N.; Valcke, R.; Frans, M.; Claes, J.E.; Van den Ende, W.; Ceusters, J. Performance index and PSII connectivity under drought and contrasting light regimes in the CAM orchid Phalaenopsis. Front Plant Sci. 2019, 10, 1012. [CrossRef]

26. Holland, V.; Koller, S.; Brüggemann, W. Insight into the photosynthetic apparatus in evergreen and deciduous European oaks during autumn senescence using OJIP fluorescence transient analysis. Plant Biol. 2013, 16, 801-808. [CrossRef]

27. Begovic, L.; Galic, V.; Abicic, I.; Loncaric, Z.; Lalic, A.; Mlinaric, S. Implications of intra-seasonal climate variations on chlorophyll a fluorescence and biomass in winter barley breeding program. Photosynthetica 2020, 58, 995-1008. [CrossRef]

28. Evans, J.R. The dependence of quantum yield on wavelength and growth irradiance. Funct. Plant Biol. 1987, 14, 69-79. [CrossRef]

29. Thomas, T.; Lei, R.T.; Kitao, M.; Koike, T. Functional relationship between chlorophyll content and leaf reflectance and lightcapturing efficiency of Japanese forest species. Physiol. Plant 1996, 96, 411-418.

30. Gibson, K.D.; Fischer, A.J.; Foin, T.C. Shading and the growth and photosynthetic responses of Ammannia conninnea. Weed Res. 2001, 41, 59-67. [CrossRef]

31. Eichelmann, H.; Oja, V.; Rasulov, B.; Padu, E.; Bichele, I.; Pettai, H.; Mand, P.; Kull, O.; Laisk, A. Adjustment of leaf photosynthesis to shade in a natural canopy: Reallocation of nitrogen. Plant Cell Environ. 2005, 28, 389-401. [CrossRef]

32. Lee, S.J.; Oh, C.Y.; Han, S.H.; Kim, K.W.; Kim, P.G. Photosynthetic responses of Populus alba x glandulosa to elevated CO 2 concentration and air temperature. Korean J. Agric. For. Meteorol. 2014, 16, 22-28. [CrossRef]

33. Taiz, L.; Zeiger, E. Plant Physiology, 4th ed.; Sinauer Associates: Sunderland, MA, USA, 2006; p. 55.

34. Popp, M.; Janett, H.P.; Lüttge, U.; Medina, E. Metabolite gradients and carbohydrate translocation in rosette leaves of CAM and C3 bromeliads. New Phytol. 2003, 157, 649-656. [CrossRef] [PubMed]

35. Poorter, H.; Perez-Soba, M. Plant growth at elevated $\mathrm{CO}_{2}$. In Encyclopedia of Global Change, Volume 2: The Earth system: Biological and Ecological Dimensions of Global Environmental Change; John Wiley and Sons: Chinchester, UK, 2002; pp. 489-496.

36. Ziska, L.H.; Hogan, K.P.; Smith, A.P.; Drake, B.G. Growth and photosynthetic response of nine tropical species with longterm exposure to doubled carbon dioxide. Oecologia 1991, 86, 383-389. [CrossRef] [PubMed]

37. Kim, H.J.; Cho, A.R.; Park, K.S.; Kim, Y.J. Effect of $\mathrm{CO}_{2}$ enrichment on growth and flowering of Phalaenopsis. Hort. J. 2017, OKD-027. [CrossRef]

38. Nogueira, A.; Martinez, C.A.; Ferreira, L.L.; Prado, C.H.B.A. Photosynthesis and water use efficiency in twenty tropical tree species of differing succession status in a Brazilian reforestation. Photosynthetica 2004, 42, 351-356. [CrossRef]

39. Zheng, W.P.; Wang, P.; Zhang, H.X.; Zhou, D. Photosynthetic characteristics of the cotyledon and first true leaf of castor (Ricinus communis L.). Aust. J. Crop Sci. 2011, 5, 702-708.

40. Hiscox, J.D.; Israelstam, G.F. A method for the extraction of chlorophyll from leaf tissue without maceration. Can. J. Bot. 1979, 57, 1332-1334. [CrossRef]

41. Arnon, D.I. Copper enzymes in isolated chloroplasts. Polyphenoloxidase in Beta vulgaris. Plant Physiol. 1949, 24, 1-15. [CrossRef]

42. Lichtenthaler, H.K. Chlorophylls and carotenoids: Pigments of photosynthetic biomembranes. Methods Enzymol. 1987, 148, 350-382. 